\title{
DOKUMENTA
}

DUŠAN BOJKOVIĆ, doktorand

Filozofski fakultet u Beogradu

dsnbojkovic@gmail.com

UDK 329.15:323.1(497.1)"1940"(093.2)

kritičko izdanje naučne građe

primljeno: 4. jul 2015.

prihvaćeno: 4. novembar 2015.

\section{JEDAN NEPOZNAT DOKUMENT KOMUNISTIČKE PARTIJE JUGOSLAVIJE O NACIONALNOM PITANJU U MAKEDONIJI, CRNOJ GORI I NA KOSOVU}

Tokom prve polovine tridesetih godina, uporedo sa naglim jačanjem nemačkog nacizma, Komunistička internacionala (KI) započela je izmenu svojih zvaničnih stavova o pitanju opstanka aktuelnih državnih struktura u Evropi. Parola borbe protiv „versajskog sistema“ povlačila se pred pozivima na odbranu granica od svakog imperijalizma, u prvom redu nemačkog i italijanskog. Politika narodnog fronta, proklamovana na Sedmom kongresu KI u Moskvi 1935, podrazumevala je u slučaju evropskih komunističkih partija privremeno napuštanje ilegalnih metoda rada, „prodor u mase“, uspostavljanje saradnje sa levo orijentisanim organizacijama i preuzimanje kontrole nad političkim životom u zemlji putem stvaranja tzv. "levih krila“ u "građanskim" strankama. ${ }^{1}$

U navedenim okolnostima Komunistička partija Jugoslavije (KPJ) napustila je parolu o neophodnosti razbijanja Kraljevine Jugoslavije, ali ne i stav o njenom „versajskom“ i „velikosrpskom" karakteru. U ovom periodu (1935-1941) rešenje nacionalnog pitanja u zemlji jugoslovenski komunisti videli su u slabljenju centralizma i formiranju „radničko-seljačkih vlada“ u Srbiji, Hrvatskoj, Sloveniji, Bosni i Hercegovini, Vojvodini, Crnoj Gori i Makedoniji. Unutar KPJ makedonsko pitanje bilo je rešeno tokom prve polovine dvadesetih godina, afirmacijom makedonske nacije. ${ }^{2} \mathrm{U}$ budućoj "samostalnoj makedonskoj republici“ nije bilo mesta za srpske dobrovoljce, naseljene u Makedoniji posle 1918, koji su u partijskoj retorici obeleženi

${ }^{1}$ Komunistička internacionala. Stenogrami i dokumenti kongresa, tom XI i XII, priredili Pero Damjanović i Radosav Đerić, (Gornji Milanovac: Institut za međunarodni radnički pokret, 1983).

2 Десанка Пешић, Јуі̄ословенски комунистии и национално йийање (1919-1935) (Београд: Рад, 1983), 55-197; Dušan Lukač, Radnički pokret u Jugoslaviji i nacionalno pitanje 1918-1941 (Beograd: ISI, 1972), 73-248; Славољуб Цветковић, Иgејне борбе у КПЈ 19191928 (Београд: ИСИ, 1985), 156-166. 
kao nosioci „velikosrpskog imperijalizma“. Uoči Drugog svetskog rata makedonski Pokrajinski komitet (PK) zagovarao je radikalno rešenje, prema kome je trebalo u celosti proterati „strani srpski element". Na Petoj zemaljskoj konferenciji KPJ održanoj oktobra 1940. u Dubravi nedaleko od Zagreba, ovi stavovi su ublaženi, mada nije govoreno o pravima srpskog naroda. ${ }^{3}$

Teza KPJ o nacionalnoj samobitnosti Crnogoraca, usvojena tokom druge polovine dvadesetih godina bez otvorene rasprave $u$ Partiji, nije imala širu podršku u narodu, ali su komunisti imali više uspeha u saradnji sa delom stanovništva koje je bilo nezadovoljno usled ukidanja crnogorske državnosti posle ujedinjenja sa Srbijom i stvaranja jugoslovenske zajednice 1918. ${ }^{4}$ Mada je uoči Drugog svetskog rata unutar KPJ problem nacionalne identifikacije stanovništva Crne Gore smatran prevaziđenim, ostalo je otvoreno pitanje granica buduće crnogorske republike. Reorganizacijom partijskih struktura na prostoru Stare Srbije (Sandžak, Kosovo i Metohija) tokom tridesetih godina nagoveštene su konture postrevolucionarnih jugoslovenskih republika Srbije, Crne Gore i Makedonije. Najpre su Kosovo i Metohija i Sandžak izuzeti iz nadležnosti PK KPJ za Srbiju i pripojeni crnogorskoj pokrajinskoj organizaciji, dok je potkraj međuratnog perioda uobličena teza o političko-etničkoj individualnosti ovih oblasti. ${ }^{5}$ Formiranjem Oblasnog komiteta (OK) KPJ za Kosovo i Metohiju 1937. definisan je okvir unutar kojeg će biti moguće razmatrati albansko pitanje u jugoslovenskim okvirima. ${ }^{6}$ Izdvajanjem OK KPJ za Kosovo i Metohiju iz sastava crnogorskog PK i uspostavljanjem neposredne veze sa CK KPJ 1940. naznačen je dalji razvoj ove oblasti u jugoslovenskoj državi posle Drugog svetskog rata. Na tragu borbe za "nacionalno oslobođenje" svih nesrpskih naroda rukovodstvo OK KPJ za Kosovo i Metohiju zahtevalo je da se „prestane sa dosadašnjim nečovječnim postupanjem prema Arnautskom narodu“ i omogući pravo na korišćenje „šiptarskog“ jezika u školskim, pravosudnim i vojnim institucijama. $^{7}$ Sveukupna partijska delatnost vođena je u cilju „ulaska u arnautske

${ }^{3}$ Arhiv Jugoslavije (AJ), fond 507, Centralni komitet Saveza komunista Jugoslavije (CK SKJ), 1940/14-1.

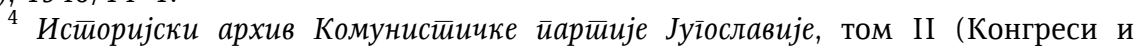
земаљске конференције КПЈ 1919-1937), (Београд: Историјско одељење Централног комитета Комунистичке партије Југославије, 1949), 145-218; Д. Пешић, н. g., 82-197; D. Lukač, n. d., 73-248.

${ }_{6}^{5}$ AJ, fond 790/1, Komunistička internacionala, 1932/173-a; 1933/480.

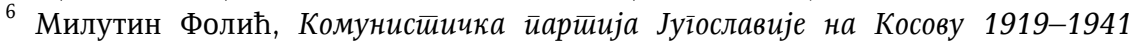
(Приштина: Јединство, 1987), 193-197; Мома Марковић, Сазревање револуиије (Сећања 1931-1941) (Београд: БИГЗ, 1984), 102-105; Milovan Djilas, Memoir of a Revolutionary (New York: Harcourt Brace Jovanovich Inc, 1973), 286.

${ }^{7}$ AJ, CK SKJ, Zbirka Srbija, I/87, 1. 
mase“. Međutim, izuzetno nizak procenat zastupljenosti Albanaca („Arnauta") u partijskim organizacijama na Kosovu i Metohiji pokazatelj je poraza nacionalne politike KPJ na tom prostoru. ${ }^{8}$ Iskustvo pokušaja saradnje komunista sa Albancima u međuratnom periodu svedoči o trajnoj i dubokoj nepoverljivosti potonjih prema revolucionarnoj partiji sa jugoslovenskim predznakom.

Sadržina dokumenta koji objavljujemo stoji u neposrednoj vezi sa navedenim problemima. Čuva se u Arhivu Jugoslavije, u fondu Centralnog komiteta Saveza komunista Jugoslavije, pod signaturom 1940/14-12, zajedno sa „Tezama o nacionalnom pitanju“ koje je sastavio Moša Pijade tokom priprema za rad Pete zemaljske konferencije KPJ. Reč je o konceptu bez glavnog naslova, u kome je razmatrano nacionalno pitanje u Makedoniji, Crnoj Gori i na Kosovu. Mada sem osnovnog teksta dokument ne sadrži nikakve napomene, komentare (izuzev treće i pete stranice koje su numerisane grafitnom olovkom brojevima 3 i 5), niti autorov potpis, gotovo sa sigurnošću se može reći da pripada Moši Pijade. Stil pisanja, sadržina i struktura ovog koncepta ukazuju na njegovu uklopljenost u Pijadine „Teze o nacionalnom pitanju“. ${ }^{9}$ Dokument je napisan na pisaćoj mašini, bez proreda, dvostrano, latinicom, na pet strana nešto većih od A4 formata. Donosimo ga u celosti, sa komentarima i objašnjenjima vezanim za određene ličnosti i događaje. Prilikom priređivanja teksta izvršene su manje intervencije u slučaju štamparskih ili pravopisnih grešaka, dok su u uglastim zagradama razvijane skraćenice i dodavani interpunkcijski znakovi, ispuštena slova i reči. Ispravkama nisu narušeni autorov stil pisanja i struktura teksta.

${ }^{8}$ Tokom 1940. unutar OK KPJ za Kosovo i Metohiju bilo je 25 Albanaca od ukupno 239 članova. Izvori za istoriju SKJ, tom I, knj. 10 (Peta zemaljska konferencija KPJ), priredili Pero Damjanović i drugi, (Beograd: Izdavački centar Komunist, 1980), 197-198.

${ }^{9}$ Svoje „Teze o nacionalnom pitanju“ Moša Pijade je podelio na sledeća poglavlja: „I Razvoj nac[ionalnog] pitanja do drugog imper[ijalističkog] rata; II Marksizam-lenjinizam i nac[ionalno] pitanje; III Nac[ionalno] pitanje u Jugoslaviji; IV KPJ i nac[ionalno] pitanje; V Nac[ionalno] pitanje u uslovima drugog imper[ijalističkog] rata; VI Jugoslavija i drugi iper[ijalistički] rat" (AJ, CK SKJ, 1940/14-12, 1). Peto poglavlje je ostalo nedovršeno, dok treće nedostaje u celosti. Otuda je moguće pretpostaviti da koncept o nacionalnom pitanju u Makedoniji, Crnoj Gori i na Kosovu predstavlja deo trećeg poglavlja „Nacionalno pitanje u Jugoslaviji“. Svoje „Teze o nacionalnom pitanju“ Moša Pijade nije dovršio, budući da su Josip Broz i Edvard Kardelj u toku priprema za rad Pete zemaljske konferencije KPJ doneli odluku da referat o nacionalnom pitanju sastavi i podnese Milovan Đilas. Njihova odluka usledila je nakon uvida $u$ Đilasove oštre komentare ispisane na marginama Pijadinih „Teza o nacionalnom pitanju“, koje, pored ostalog, svedoče o prirodi odnosa dva revolucionara. Referat Milovana Đilasa o nacionalnom pitanju nije sačuvan. Videti: Izvori za istoriju SKJ, tom I, knj. 10, 378-400, 509, 554-555, 584-585. 


\section{Nacionalno pitanje $\mathbf{u}$ Makedoniji ${ }^{10}$}

1) Uvod: Sve do [Prvog] balkanskog rata [1912] makedonsko nac[ionalno] pitanje bilo je u osnovi pitanje burž[oasko]-demokratske revolucije, a osnovni vladajući elemenat bila je tako feudalna klasa. Sad [1940. prim. D. B.] se pitanje makedonskog nac[ionalnog] oslobođenja postavlja kao pitanje dovršavanja burž[oasko]-demokratske revolucije: Pitanje borbe protiv triju imperijalizama (srpskog, bugarskog i grčkog).

2) Konkretne forme nac[ionalnog] ugnjetavanja Makedonije.

a) Buržoazija oseća nac[ionalno] ugnjetavanje u raznim oblicima: 1) Makedonija je za Srbe i Grke u osnovi kolonijalno područje na kome vladajuća nacija dozvoljava razvitak samo u toliko u koliko odgovara potrebama vladajuće klase vladajuće nacije (sirovine). 2) Zatim, makedonska buržoazija oseća se podvlašćena i carinskom, poreskom, saobraćajnom, kreditnom itd. politikom države i njenih kreditnih ustanova. 3) Jedan de[o] trgovačke buržoazije pogođen je podelom Makedonije, tj. razbijanjem jedinstvene oblasti koja je ranije bila važna raskrsnica mnogobrojnih trgovačkih puteva. Niz gradova koji su ranije bili centri žive trgovine (na pr[imer] Bitolj) sada je morao propasti, a našta je buržoazija ovih gradova gledala kao na posledicu nac[ionalne] podvlašćenosti. ${ }^{11}$

b) Sitna buržoazija u makedonskim varošima: 1) Naročito posle rata oseća pojačanu konkurenciju industrijskih proizvoda iz ostalih delova Jugoslavije, Grčke i Bugarske. 2) Osećaju se zapostavljeni u kreditnoj i poreskoj politici. 3) Počinje ubrzana pauperizacija tih slojeva. 4) Ovi slojevi oštro reagiraju također na sve vrste kulturnog (srbiziranje) i političkog ugnjetavanja.

c) Bedno seljaštvo oseća nac[ionalno] ugnjetavanje u najrazličitijim formama. Pre svega ono oseća da je imperijalističko „rešenje“ nac[ionalnog] pitanja u bivšoj Turskoj sprečilo njegovo revoluc[ionarno] rešenje pa prema tome i rev[olucionarno] rešenje feudalnih agrarnih odnosa u Makedoniji. Srbi su [od] 1913. do 1918. odugovlačili sa rešenjem agrarnih odnosa.

${ }^{10}$ AJ, CK SKJ, 1940/14-12, [prilog,] 1-5.

11 Jugoslovensko-grčka granica presecala je vardarsku dolinu i bitoljsko-lerinsku ravan, odnosno skopsko-solunsku i bitoljsko-solunsku komunikaciju. Kidanje starih saobraćajno-trgovačkih veza i odumiranje trgovačkih čvorišta uslovilo je opadanje broja stanovnika u svim gradovima Makedonije i Stare Srbije. Posle 1918. značaj Kosovske Mitrovice naglo je opao jer su stare veze bivšeg Novopazarskog sandžaka sa trgovačkim centrima na jugu preusmerene ka Sarajevu. Proces odumiranja gradova i varoši u Makedoniji nije, međutim, bio uslovljen jedino politikom srpskih/jugoslovenskih vlasti posle Balkanskih ratova. Procenjuje se da je do 1912. iz ove oblasti u pečalbu otišlo preko 70.000 ljudi. Više: Владан Јовановић, Јуіословенска држава и Јужна Србија 1918-1929 (Београд: ИНИС, 2002), 48-53; Владан Јовановић, Варgарска бановина 1929-1941 (Београд: ИНИС, 2011), 16-17. 
Zakoni od 1931-33. god[ine] u stvari su dobar deo seljaka opteretili vrlo visokim nametima. Dalje, makedonski seljak tek $u$ Srbiji vidi prvi put modernu burž[oasku] državu sa silnim birokratsko-policijskim aparatom, poreskim pritiskom itd. $\mathrm{Na}$ taj način mak[edonski] nac[ionalni] pokret sadrži i elemenat nekadašnjeg srpskog radikalizma.

Seljaštvo također oseća kako ga vladajuća nacija ugnjetava i na pitanju podele drž[avnih] šuma i pašnjaka, na pitanju kolonizacije, zatim što država oduzima mak[edonskom] seljaštvu vrlo često deo opštinskih zemalja u cilju kolonizacije državotvornih elemenata itd. Nezadovoljstvo seljaka još se povećava zbog protekcionaške politike drž[avnih] kreditnih ustanova ( $\mathrm{PAB},{ }^{12} \mathrm{DHB}^{13}$ itd), državne poreske politike, nametanja protivnarodnih, opštinskih odbora, brutalnog forsiranja asimilacije Makedonaca, divljačkih metoda žandarmerije i kontrakomiteta, eksploatatorskih metoda države i trgovaca u odnosu prema seljacima, proizvođačima duvana, opijuma, pirinča itd. Najzad, svoje sve jače i jače zaduživanje i agrarnu krizu seljaštvo takođe posmatra kao rezultat srpskog odn[osno] grčkog imperijalizma.

d) Proletarijat oseća nac[ionalno] ugnjetavanje: 1) U obliku mnogo nižeg standarda života. 2) Kao sezonski seljak (pečalbar) on podnosi niz šikana i izrabljivanja od strane policijskih vlasti. 3) U državnim preduzećima oseća se protežiranje srbijanskih elemenata.

3) Klasa i partija i njihov odnos prema nac[ionalnom] pitanju. U ovoj tački ograničićemo se u glavnom na podatke o srpskoj Makedoniji, zaključci do kojih budemo došli važe u osnovi i za Makedonce pod Grcima i Bugarima.

a) Krupna buržoazija Makedonaca u koliko je ima vodi u osnovi dvostruku politiku. 1) S jedne strane ona javno sarađuje sa režimom imperijalista (srpskim odnosno bugarskim i grčkim) pošto bi joj inače bilo nemoguće da dođe do nekih profita (to na primer važi za razne provincijske banke, za trgovce itd). Šta više, jedan njen deo potpuno se povezao sa buržoazijom vladajuće nacije (Ovo se naročito jasno vidi u Bugarskoj gde makedonski komitet već 40 god[ina] igra ogromnu ulogu u unutrašnjoj politici). S druge strane, veliki deo te buržoazije nije zadovoljan sa postojećim stanjem već želi da se ono izmeni. To uglavnom važi za buržoaziju u srpskoj i grčkoj Makedoniji, koja teži za prisajedinjenje Makedonije Bugarskoj - po mogućnosti na bazi izvesne autonomije u okviru takve Velike Bugarske. Izraz ove težnje velikog dela buržoazije za imp[erijalističkim] rešenjem nac[ionalnog] pitanja u Makedoniji jeste reakcionarno desno krilo

\footnotetext{
${ }^{12}$ Privilegovana agrarna banka.

${ }^{13}$ Državna hipotekarna banka.
} 
u VMRO ${ }^{14}$ (danas krilo Vanče Mihailova ${ }^{15}$ ), koje je najuže povezano sa bugarskim dvorom i bugarskim kapitalom.

b) Verska sitna buržoazija sa inteligencijom je već pola veka rukovodeći element u maked[onskom] pokretu, pa su i danas vrlo važan faktor $u$ njemu (jer su žestoko pogođeni nac[ionalnim] ugnjetavanjem). Stav tog sloja nije jedinstven. Veći njegov deo naginje polit[ičkoj] liniji Vanče Mihailova. Manji deo povezuje se sa seljaštvom i drži se stare federalističke polit[ičke] linije. To su takozvani federalisti (VMRO ob[j]edinjeni) koji su od 1923-24. išli linijom Čauljev ${ }^{16}$-[Todor] Panica. ${ }^{17}$ Njihova je parola samostalna demokratska Makedonija u sastavu Balkanske Federacije.

c) Seljaštvo. 1) Kulački elementi su i ovde kao i svugde raspoloženi oportunistički. 2) Radno seljaštvo je, međutim, objektivno nosilac nac[ionalno] rev[olucionarnog] pokreta sa parolama koje dolaze do izražaja $\mathrm{u}$ federalističkom krilu makedonskog nac[ionalno] rev[olucionarnog] pokreta. Subjektivno, ono u slobodnoj Makedoniji vidi potpunu likvidaciju feudalnih agrarnih odnosa bez ostat[k]a kao i ukidanje svih oblika izrabljivanja i polit[ičkog] ugnjetavanja kojima je sada podvrgnuto. Ali njegov polit[ički] aktivizam, sasvim prirodno, nije uvek u skladu sa njegovim objektivnim interesom. U znaku otpora protiv srpskog i grčkog ugnjetavanja to je seljaštvo kroz dugi niz godina posle rata svim sredstvima podupiralo rad VMRO (reakcionarnog dela). Tek kad se u Bugarskoj demaskirala uloga VMRO kao oruđa fašizma i imperijalizma, od tada su započela ona divlja

${ }^{14}$ Unutrašnja makedonska revolucionarna organizacija (VMRO; mak. Bнā̄peuнa макеgонска револуиионерна орїанизаиија) osnovana je u Solunu 1893, u cilju pokretanja borbe za ujedinjenje Vardarske, Pirinske i Egejske Makedonije u jedinstvenu autonomnu oblast u okviru Osmanskog carstva. Posle 1918. VMRO se u svom radu oslanjala na desno orijentisane elemente u Bugarskoj. Pripadnici levice unutar VMRO, okupljeni oko Dimitra Vlahova, Petra Čauljeva, Todora Panice, otcepili su se 1925. i uz podršku KI formirali tzv. objedinjenu VMRO (mak. обеguнет̄a). Ostatak organizacije nastavio je sa rad pod starim nazivom, tesno sarađujući sa ustašama u Jugoslaviji. Više: Михаило Апостолски и други, Истиорија макеgонскої нароgа (ИМН), I-III (Београд: Завод за издавање уџбеника СРС, 1970), III/153-221; В. Јовановић, Јуїословенска држава и Јужна Србија 1918-1929, 173-

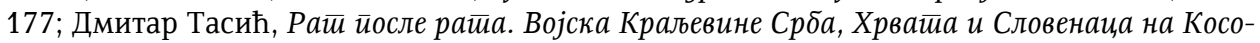
ву и Мейохији и у Макеgонији 1918-1920 (Београд: Утопија, 2008), 120-228; Vladeta Milićević, Ubistvo kralja u Marselju. Pozadina jednog zločina (Beograd: Filip Višnjić, 2000), 27-66.

${ }^{15}$ Ivan Vančo Mihajlov (Novo Selo, 1896 - Rim, 1990) bio je jedan od predvodnika desnog krila VMRO. - Đorđe Ličina i drugi, Andrija Artuković, Vjekoslav Luburić, Džafer Deva, Vančo Mihailov (Zagreb: Centar za informacije i publicitet, 1985), 265-336.

${ }^{16}$ Petar Čauljev (Ohrid, 1882 - Milano, 1924) bio je komitski vojvoda i član Centralnog komiteta (CK) VMRO. Učestvovao je u Ilindenskom ustanku 1903, a tokom Balkanskih ratova borio se na strani Bugarske.

${ }^{17}$ Todor Panica (Orjahovo, nedaleko od Plevena, 1879 - Beč, 1925). Bugarski revolucionar, jedan od osnivača VMRO. 
klanja između dve frakcije u VMRO. To u toliko pre što se usled tih borbi potpuno izgubila akciona sposobnost VMRO-a na terenu.

Razume se da je time data i objektivna mogućnost da istinski mak[edonski] nac[ionalni] revolucionari (federalisti) obuhvate najšire mase seljaštva. To će znatno biti olakšano pojedinačnim nezadovoljstvom usled agrarne krize itd. Svakako je jasno da makedonsko seljaštvo danas dovršava pod rukovodstvom proletarijata ono što buržoazija nije mogla da dovrši, a to je konstituisanje Makedonaca kao nacije. Danas ili sutra to će morati da dođe do izražaja u velikom masovnom pokretu maked[onskog] seljaštva na teritoriji svih triju država.

d) Proletarijat je po prirodi stvari najradikalniji elemenat $u$ maked[onskom] nac[ionalnom] pokretu. Ali on ima ne samo da stane na čelo maked[onskog] nac[ionalno] rev[olucionarnog] pokreta nego da takođe dadne makedonskoj naciji one [e]lemente nadgradnje koji još nedostaju za dovršavanje punog jedinstva te nacije (jedinstva jezika, pravopisa, kulture).

e) VMRO: 1920 god[ine] makedonske mase su masovno glasale za KPJ. ${ }^{18}$ Posle sloma Vukovarske KPJ ${ }^{19}$ VMRO je opet dobio na uticaju. Sve do 1924. na terenu radi ceo niz komitskih grupa, pa čak i srpske partije na izborima 1923. pravile su tajne paktove sa eksponentima VMRO. 1924 posle dugih pregovora Todor Aleksandrov, ${ }^{20}$ [Aleksandar] Protagorov, ${ }^{21}$ [Petar] Čauljev potpisali su u sporazumu sa kombalkanskom federacijom ${ }^{22}$ jedan manifest ${ }^{23}$ kojim se makedonske mase pozivaju u borbu za slobodnu federaciju rad[ničko]-selj[ačkih] republika Balkana, koja će uključivati i samostalnu Makedoniju, pa je na toj platformi izvršena reorganizacija pod imenom VMRO (ob[j]edinjena). Međutim pod pritiskom bugarskog kapitala, oficira i dvora koji su [se] već 9. VI i septembra 1923. poslužili potporom

${ }^{18} \mathrm{Na}$ izborima za Konstituantu 1920. KPJ je sa dobijenih 198.736 glasova zauzela četvrto mesto među parlamentarnim strankama. Komunisti su dobili većinu u Crnoj Gori sa $25 \%$ glasova ( 4 mandata) i Makedoniji sa $20 \%$ glasova (15 mandata), dok su u Staroj Srbiji osvojili znatno manje: $8 \%$ glasova ( 3 mandata). Od ukupno 59 poslaničkih mandata u Ustavotvornoj skupštini koje su osvojili komunisti, četvrtinu (15) su obezbedili glasovi iz Makedonije. Branislav Gligorijević, Parlament i političke stranke u Jugoslaviji (1919-1929) (Beograd: ISI, 1979), 82-84; Ivo Banac, Nacionalno pitanje u Jugoslaviji. Porijeklo, povijest, politika (Zagreb: Globus, 1988), 308-309.

${ }^{19}$ Misli se na proglašenje „Obznane“ (decembar 1920) i Zakona o zaštiti države (avgust 1921) kojima je, pored ostalog, zabranjen rad KPJ.

${ }^{20}$ Todor Aleksandrov (Novo Selo, 1881 - Sugarevo, 1924). Komitski vojvoda i član CK VMRO. U ratovima 1912-1918. borio se na strani Bugarske.

${ }^{21}$ Umesto „Protagorov“ treba „Protogerov“. Aleksandar Protogerov (Ohrid, 1867 Sofija, 1928), bugarski general, političar, komitski vojvoda i član CK VMRO.

${ }^{22}$ Misli se na Balkansku komunističku federaciju (BKF).

${ }^{23}$ Misli se na tzv. Majski manifest sastavljen u Beču 6. maja 1924, kojim je potvrđena saradnja VMRO i BKF u cilju borbe za „nacionalno oslobođenje ugnjetenih naroda“ u Makedoniji i ostalim pokrajinama na Balkanu. 
VMRO-a protiv bugarskih seljaka i radnika, [Todor] Aleksandrov i [Aleksandar] Protagorov uskoro su se odrekli tog jednog - frontovskog manifesta. Tada [1925. - prim. D. B.] se [Petar] Čauljev sa manjim delom VMRO-a otcepio i ostao na liniji VMRO-a - ob[j]edinjenoj, tj. federalista čiji je ideološki eksponent bio [Dimitar] Vlahov ${ }^{24}$ (urednik časopisa „Balkanska Federacija“). Od tada datira krvava borba u kojoj su najpre izgubili glavu prestavnici federalista ${ }^{25}$ a koja je uskoro prešla u borbu između Aleksandrovista (danas mihailovista) i protagorovista. U ovoj potajnoj borbi prva se frakcija oslanjala na dvor i na L[j]apčevljevu ${ }^{26}$ grupu, Englesku, Italiju. Protagorovisti su kako po svemu izgleda docnije tražili naslon na Beograd, a u Bugarskoj su se u prvo vreme oslanjali na grupu oko [Aleksandra] Cankova. ${ }^{27} \mathrm{Na}$ taj način se je VMRO pretvorio u običnu organizaciju plaćenika koja ima mnogo veći značaj u unutrašnjim polit[ičkim] borbama u Bugarskoj nego za razvoj prilika u Makedoniji. Kao što znamo, VMRO [je] u osnovi sitnoburžoaska organizacija ali zavisna od krupno-buržoaskih elemenata u redovima makedonskih „bratstava“ u Bugarskoj. Po svojim metodama borba VMRO se ograničavala na individualne akcije, te na demonstrativne aktove koji imaju da svrate pozornost Evrope na makedonsko pitanje. Stvarno rešenje makedonskog pitanja očekuje i VMRO od novog imperijalističkog rata. Ta jednakost metoda omogućila je još pre 1919. a naročito posle 1929. saradnju mihailovista i frankovaca. ${ }^{28}$

f) Nac[ionalna] manjina. Ne sumnjivo je da [je] sav gornji sloj posleratnih kolonista u stvari direktna ekspozitura imperijalista, režima srpskog i grčkog. Međutim je isto tako jasno da [je] ova osnovna masa nac[ionalnih] manjina solidarna s makedonskim masama u borbi za slobodu Makedonije. Vrlo je verovatno da će baš ta zajednica otpora dovesti do spontanog procesa asimilacije tih raštrkanih nac[ionalnih] manjina i etničkih grupa, a to bi znatno pojednostavilo nac[ionalno] pitanje.

4) Zaključci.

a) U okviru razvitka kapitalizma Makedonci nisu dospeli da se $u$ punoj meri konstituišu kao nacija.

${ }^{24}$ Dimitar Vlahov (Kukuš, 1878 - Beograd, 1953). Makedonski revolucionar, publicista, potpredsednik Antifašističkog veća narodnog oslobođenja Jugoslavije (1943), predsednik Prezidijuma Narodne skupštine Narodne Republike Makedonije, član CK KP Makedonije i Centralne revizione komisije KPJ.

${ }^{25}$ Misli se na ubistvo Petra Čauljeva 1924. i Aleksandra Protogerova 1928.

${ }^{26}$ Andrej Ljapčev (Resen, 1866 - Sofija, 1933). Bugarski premijer od 1926. do 1933.

${ }^{27}$ Aleksandar Cankov (Orjahovo, 1879 - Buenos Ajres, 1959). Bugarski premijer od 1923. do 1926.

${ }^{28}$ Misli se na članove i simpatizere Čiste stranke prava, odnosno Hrvatske stranke prava, koju je osnovao Josip Frank. 
b) U epohi raspadanja kapitalizma (tj. imperijalizma) maked[onska] buržoazija nužno igra ulogu eksponenata imperijalističkih sila. Ulogu kontrarevolucionarnu.

c) U toj epohi seljaštvo nužno postaje osnovni nosilac maked[onskog] nac[ionalnog] pokreta pa i time nosilac dovršavanja formiranja maked[onske] nacije.

d) Međutim, zadatak potpunog konstituisanja te nacije i njenog stvarnog oslobođenja seljaštvo može da ispuni samo ako vodstvo nac[ionalno] rev[olucionarnog] pokreta uzme u svoje ruke mak[edonski] proletarijat.

e) VMRO je kroz d[v]e decenije bio glavna borbena organizacija Makedonaca koja se oslanjala na sve slojeve Makedonije. Međutim, naročito od 1924. g[odine] on postepeno gubi potporu maked[onskog] seljaštva i radništva izobličavajući se sve više i više kao prosta ekspozitura bugarskog imperijalizma.

f) Kao osnovno jezgro istinskog nac[ionalno] rev[olucionarnog] pokreta javlja se od 1924. g[odine] organizacija federalista (na liniji tradicija [Goce] Delčeva i [Janeta] Sandanskog ${ }^{29}$ ).

g) Oslobođenje Makedonije moguće je samo na temelju rad[ničko]selj[ačke] revolucije koja znači dovršavanje burž[oasko]-de[mokratske] revolucije koja se u svom stadiju javlja kao obaranje srpskog, grčkog i bugarskog imperijalizma, nad Makedonijom.

h) Osiguranje i utvrđenje tog oslobođenja moguće je samo ako rad[ničko]-selj[ačka] revolucija pređe u proletersku revoluciju i diktaturu proletarijata, jer samo ona ukida samu mogućnost svakog nac[ionalnog] ugnjetavanja i garantuje punu [i] najširu primenu rev[olucionarnog] demokratskog principa prema susjednim nacijama kao i prema nac[ionalnim] manjinama same Makedonije.

\section{Nacionalno pitanje u Crnoj Gori}

1. Forme nac[ionalnog] ugnjetavanja:

a) Buržoazija oseća prevlast srbijanskog kapitalizma slično kao u Makedoniji.

b) Sitna buržoazija je uglavnom isto tako kao i u Makedoniji.

c) Seljaštvo nac[ionalno] podjarmljivanje koje počinje sa ujedinjenjem za seljaštvo je istovetno sa kapitalističkim poretkom, sa ukidanjem dr[u]gih ostataka gentilnih uredaba i sloboda (napr: otuđivanje zajedničkih plemenskih šuma i ispaša). Ono znači javljanje sitnog birokratsko-

${ }^{29}$ Goce Delčev (Kukuš, 1872 - Banica, 1903), Jane Sandanski (Vlahi, 1872 - Nevrokop, 1915) bili su predvodnici autonomističke struje unutar VMRO. 
političkog aparata, [ra]nije nepoznatog u Crnoj Gori, znatno povećavanje poreskog pritiska, ukidanja plemenske vojske, uvođenje stajaće vojske (nezavršeno pod kraljem Nikolom) razoružavanje naroda, ubrzani proces pauperizacije. Uz to je crnogorsko seljaštvo jako pritisnuto politikom državnog kapitala (duvan), državnim i opštim porezima i taksama i strahovitim žandarmerijskim terorom koji u nekim oblastima Crne Gore vlada već 15 godina. Teret agrarne krize, nesrazmerno visoke cene hrane (220 dinara za $100 \mathrm{~kg}$ kukuruza u oktobru 1935. kad je cena na veliko u Vojvodini 80-90 din[ara]), sve veća nemogućnost iseljavanja i sve jače zaduživanje - sve se to u očima seljaštva odražava kao plod veliko-srpskog imperijalizma.

d) Proletarijat. Za proletarijat Crne Gore važi isto što i za proletarijat Makedonije.

2) Klase i partije prema crnogorskom nac[ionalnom] pitanju.

a) Buržoazija: Slabost sloja crnogorske buržoazije, njen strah od socijalne revolucije i uskost same crnogorske ekonomske baze, njen sopstven[i] razvitak [-] sve to čini da je ona i dalje eksponent veliko-srpske hegemonije (bankar, industrijalac, pretsednik cetinske opštine i narodni poslanik JNS ${ }^{30}$ Nikola Zuber ${ }^{31}$ ). Taj sloj je za održanje današnjeg uređenja i ne simpatizira sa tendencijama afirmacije Crnogoraca kao nacije. Taj sloj podupire razne veliko-srpske stranke ( $\mathrm{JRZ}^{32}$, JNS, radikale ${ }^{33}$ i demokrate $^{34}$ ).

b) Varoška sitna buržoazija: 1) Jedan njen deo orjentiran je kao i krupna buržoazija. 2) Veći njen deo kao i veliki deo same inteligencije orjentiše se crnogorski nacionalno ili barem federalistički. Federalisti ${ }^{35}$ (Savo Vuletić, pok. [Mihailo] Ivaković, ${ }^{36}$ nekada i Sekula Drljevićc ${ }^{37}$ ) su najtipičniji izraz težnje za kompromisnim rešenjem crnogorskog nac[ionalnog]

${ }^{30}$ Jugoslovenska nacionalna stranka.

${ }^{31}$ Nikola Novaković Zuber bio je član Narodne stranke i jedan od pokretača lista „Slobodna riječ“, koji se kritički odnosio prema crnogorskim vlastima u vreme vladavine

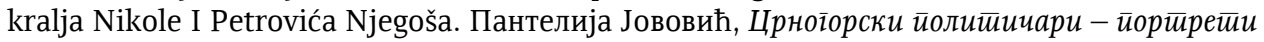
(Београд: Штампарија „Време“, 1924), 35-36.

32 Jugoslovenska radikalna zajednica.

${ }^{33}$ Radikalna stranka.

${ }^{34}$ Demokratska stranka.

${ }^{35}$ Pokret federalista u Crnoj Gori iznikao je na osnovama borbe tzv. zelenaša protiv odluke Podgoričke skupštine 1918. o ujedinjenju Crne Gore sa Srbijom pod dinastijom Karađorđević. Više: Димитрије Димо Вујовић, Црноіорски феgералистии 1919-1929 (Титоград: Црногорска академија наука и умјетности, 1981).

${ }^{36}$ Umesto „Ivaković" treba „Ivanović".

37 Tokom Prvog svetskog rata Sekula Drljević, Mihailo Ivanović i Savo Vuletić zalagali su se za ujedinjenje „dve srpske države“. Međutim, posle 1918. nalazili su se među najistaknutijim protivnicima dinastije Karađorđević. Sekula Drljević se među ostalim federalistima izdvajao svojim antisrpskim raspoloženjem, koje ga je tokom tridesetih godina približilo ustaškom pokretu. Bio je jedan od zagovornika pseudonaučne teze o Crnogorcima kao „Crvenim Hrvatima“. 
pitanja. Oni su proizašli iz nekadašnjeg zelenaškog protivsrpskog pokreta 1920-24. kao oformljenje njegovog kompromisnog desnog krila. Prirodno je da su oni već ranije tražili i našli izvesni oslonac u HSS. ${ }^{38}$

c) Seljaštvo iz razloga koji su napred navedeni (pod 1) crnogorsko je seljaštvo vrlo oštro reagiralo na srbijanski imperijalizam naročito u periodu velike „komitske“ akcije, nac[ionalno] rev[olucionarne] akcije 1921-24. g[odine], dakle posle razbijanja KPJ, koja je 1920. ovde imala ogromne masovne simpatije. U toj borbi koja ni do danas nije i ne može biti likvidirana nego samo zaoštrena, crnogorsko seljaštvo vrši ono što buržoazija nije mogla, to jest da koristi crnogorsku naciju, da postaje osnovnim nosiocem njenog formiranja. Treba i ovde istaći da pitanje socijalnog oslobođenja, svog oslobođenja ispod jarma policijskog pritiska, bede i zaostalosti, čitavo to pitanje seljaštvo gleda kroz prizmu nac[ionalnog] oslobođenja. T[o] je seljaštvo 1920. god[ine], glasalo u tome smislu za kompartiju i za republikanc $[\mathrm{e}]^{39}$ koji su imali federalistički program (Jovan Đonović ${ }^{40}$ danas prirepak Bele [r]uke ${ }^{41}$ ). 1920-24. god[ine] seljaštvo je podržavalo komitske akcije, a 1923-27. ono je dalo najve[ć]i broj federalističkih glasova (na taj način i federalisti su u stvari seljačka partija sa varoškim sitno-buržoaskim vodstvom).

Zemljoradnička stranka ${ }^{42}$ baš zato što je izrazito veliko-srpska (bar po tom pitanju Novica Šau[1]ić i Stojan Cerović ${ }^{43}$ ) nije nikada uspela da okupi oko sebe mase, mada je na izborima 1927. g[odine] dobila jedan mandat. Ukratko: crnogorsko seljaštvo i do danas [j]e ostalo glavni rezervoar rev[olucionarnog] pokreta za crnogorsko nac[ionalno] oslobođenje.

d) Proletarijat i ovde kao i svuda neophodan je i prirodan saveznik i vođa seljaštva u borbi za nac[ionalno] oslobođenje.

3) Zaključak:

a) I u Crnoj Gori je seljaštvo glavni nosilac završavanja procesa [ko]nstituisanja Crnogoraca kao nacije i njihove borbe za nac[ionalno] oslobođenje. Ta nac[ionalno] oslobodilačka borba jeste u stvari izraz njegove borbe za oslobođenje ispod jarma kapitalističke eksploatacije i za proši-

${ }^{38}$ Hrvatska seljačka stranka.

${ }^{39}$ Misli se na Jugoslovensku republikansku stranku (JRS).

40 Jovan Đonović je, uz Marka Dakovića i Todora Božovića, bio jedan od predvodnika crnogorske omladine čija su se politička načela kosila sa politikom knjaza, potom kralja, Nikole I Petrovića Njegoša. U sudskom procesu vezanom za učešće u tzv. bombaškoj aferi 1907. osuđen je na smrt, ali je pomilovan 1912. Posle Prvog svetskog rata pripadao je JRS.

${ }^{41}$ Tajna oficirska organizacija pod nazivom „Bela ruka“ na čelu sa komandantom kraljeve garde generalom Petrom Živkovićem bila je bliska Dvoru i dinastiji Karađorđević.

${ }_{42}$ Misli se na Savez zemljoradnika (SZ).

${ }^{43}$ Stojan Cerović i Novica Šaulić nalazili su se na čelu SZ u Crnoj Gori. Njihova programska načela nalagala su suzbijanje „plemenskih" i „pokrajinskih sukoba“ i učvršćenje jugoslovenske države. 
renje mogućnosti njegovog ekonomskog razvitka na bazi razvitka produktivnih snaga kojima su današnji imperijalistički odnosi silna zapreka. U ovoj etapi ona je izraz težnje crnogorskog seljaštva za sopstvenom crnog[orskom] selj[ačkom] republikom.

b) Međutim, seljaštvo može postići taj cilj i osigurati svoje tekovine samo ako mu rev[olucionarni] proletarijat bude saveznik i vođa, dak[le] ako se oslobodi današnjeg sitno buržoaskog kompromisnog vođstva iz redova federalističke stranke. ${ }^{44}$

\section{Nacionalno pitanje na Kosovu}

Istorijsko-geografski pojam Kosova obuhvata teritoriju Kosova Polja iz[međ]u Prištine, Kačanika, Zvečana i Drenice.

Političko-etnički obuhvata Kosovo sve ono što su Srbija i Crna Gora os[voji]le na jugu odnosno na zapadu i istoku 1912-13. ako izuzmemo teritoriju Ma[kedo]nije. Uključujemo dakle ovamo u principu i čitav bivši Novopazarski Sandžak kao i kraj oko Đakovice i Peći (Metohija). ${ }^{45}$

1) Forme nac[ionalnog] ugnjetavanja. Sve do 1924. ovde je tolerirana partijska for[mac]ija muslimana (Džemijati ${ }^{46}$ ) pod vodstvom feudalnih elemenata, jer je ona bi[la] potrebna radikalima ne samo u parlamentu već i na terenu.

Bilo je to vreme [kada] je državni aparat bio još toliko slab da je morao paktirati i sarađivati i sa raznim često polurazbojničkim šefovima arnautskih fisova i manji[na]ma (napr: sa Dreničkim gospodarom Azem Bejtom $^{47}$ čija je reč ovde tada više [zna]čila nego reč državnih vlasti). Ali kada se državna vlast osetila dovoljno [jak]om ona je srušila ne samo topovima

${ }^{44}$ Ispod ovog pasusa nalazi se velika belina (polovina stranice) što možda svedoči o autorovoj nameri naknadnog unosa teksta.

45 Nijedan od dva ponuđena kriterijuma - „istorijsko-geografski“ i „političkoetnički“ - ne odgovaraju međuratnoj retorici KPJ, jer pod terminom „Kosovo“ komunisti gotovo nikada nisu podrazumevali Kosovo polje niti Staru Srbiju. Gledište izneto u ovom tekstu bliže je komunistima starije generacije koji su o „Kosovu“ često govorili neodređeno, poistovećujući taj pojam sa teritorijom južno od linije srpsko-turskog razgraničenja iz 1878.

46 Džemijet (tur. cemivet - družba, skup) je delovao na prostoru Stare Srbije i Makedonije. Stranka je imala stabilno glasačko jezgro u gradskim sredinama. Svoje pristalice, pre svega iz redova albanske i turske nacionalne manjine, okupljao je na verskoj osnovi. U periodu od osnivanja stranke 1919. do zabrane njenog rada 1925, vođi Džemijeta uglavnom su sarađivali sa režimskim strankama, u prvom redu sa radikalima. Više: Богумил Храбак, Џемијей: оріанизација муслимана Макеgоније, Косова, Меиохије и Санцака 19191928 (Београд: ВМД, 2003).

${ }^{47}$ Azem Bejta (Galica, 1889 - Junik, 1924). Predvodnik albanskih kačaka iz okoline Drenice. Učestvovao je u borbama protiv srpske/jugoslovenske vojske i vlasti u periodu od Balkanskih ratova do 1924. 
kulu Azem Bejta već je potpuno onemogućeno svako parlamentarno zastupstvo Turaka, slovenskih Muslimana ${ }^{48}$ i Arnau[ta].

b) Kosovo je postalo i oblast glavne kolonizacije srpskih elemenata. Ta [se] kolonizacija vrši u znaku otimanja zemlje (ispaše, utrine, šume) domaćeg mu[sli]manskog, naročito arnautskog [stanovn]ištva. Današnjim siromašnim seljacima [ne] daje se nikakva zemlja a naseljavaju se Srbijanci (četnici, komit[ske] „vojvode“, [Crn] ogorci pa čak i Vojvođani, Baranci i Istrani). Plodno Kosovo i Drenica pa[li] su u ruke kolonistima. Naročito u prvoj fazi kolonizacije Metohije režim je naprosto otimao najbolje zemlje plodnoj Metohiji i delio ih naročito Crnogorskim oficirima. ${ }^{49}$

c) Kosovo je pos[ta]lo tada tipična kolonijalna oblast. Kao i Makedonija, Koso[vo] je područje koje srbijanski i strani kapital eksploatiše na razne načine. [Do]maće seljaštvo ako izuzmemo nešto turskih begova i trgovaca i nekoliko sr[pskih] sastoji se od zanatlija, seljaka i sitnih trgovaca (u najboljem slučaju). [Da]kle ni govora o nekoj znatnijoj akumulaciji domaćeg kapitala.

d) Kao i Makedonija, Kosovo je oblast poreski eksploatisana. Podela budžeta [n]e dovodi u te krajeve ni iz daleka onoliko koliko ta oblast daje $\mathrm{u}$ obliku [p]oreza i drugih dažbina.

e) Samo seljaštvo tih krajeva kao i u Makedoniji trpi i zbog toga što država drži sve šume što joj omogućuje proizvoljan pritisak na seljake koji imaju prava sarviteta u tim šumama. Nedostatak vode u nekim mestima, rđava saobraćajna veza [-] sve to direktno pogađa široke mase ove zemlje.

f) Kao i u Makedoniji i ovde je još otvoreno pitanje bivših feudalnih odnosa. Pitanja odnosa [nečitko - prim. D. B.] (napoličara), [nečitko -

${ }^{48} \mathrm{U}$ originalu dokumenta termin „muslimani“, odnosno „slovenski muslimani“ javlja se u dva oblika: sa velikim ili sa malim početnim slovom „M“. Prvi slučaj upućuje na isticanje nacionalne, odnosno etničke individualnosti „Muslimana“, dok je u drugom reč o verskoj identifikaciji jednog dela slovenskog stanovništva. Nedoslednost u odnosu KPJ prema muslimanima slovenskog porekla prisutna je u međuratnom, ratnom, pa i posleratnom periodu.

${ }^{49}$ Za potrebe nastanjivanja kolonista korišćeno je slobodno državno zemljište, opštinske i seoske utrine, trajno napuštena zemljišta, imanja odmetnika i ljudi stavljenih van zakona, potom plodno šumsko tlo, zemljišta koja je trebalo urediti meliorizacijom i isušivanjem. Takođe, Ministarstvo poljoprivrede vršilo je otkup privatnog zemljišta. Pored planskog naseljavanja slovenskog elementa dolazilo je do pojave autokolonista, koji su se, poput Crnogoraca u Metohiji, nastanjivali samostalno, uzurpacijom ili kupovinom zemlje. Tek u periodu od 1936. do 1939. jugoslovenske vlasti su započele obimnije oduzimanje zemlje koja se nalazila u posedu Albanaca, pri čemu je predviđeni zemljišni minimum po članu domaćinstva iznosio 0,40 ha. Više: Vladan Jovanović, „Tokovi i ishod međuratne kolonizacije Makedonije, Kosova i Metohije“, Tokovi istorije, 3, (2006), 25-44; Zoran Janjetović, Deca careva, pastorčad kraljeva. Nacionalne manjine u Jugoslaviji 1918-1941 (Beograd: INIS, 2005), 331-335. 
prim. D. B.] još je nerešeno, odnosno zakoni od 1931. i 1933. ${ }^{50}$ god[ine] traže od tih siromašnih seljaka o[d]štetu veleposednicima, begovima pa čak i državi, ostaju velike površine u rukama manastira i vakufa kao i same države, takozvani zemljišni kolonizacioni fond.

g) Dobar deo kolonista nije u ružičastom položaju. Makar u izvesnoj meri pomagani preko agrarnih zajednica od države, mnogi od njih nisu uspeli da se održe. Iz raznih razloga (neobično rđava tehnička kolonizacija itd) propala su čak i čitava nova naselja. U redovima ostalih započeo je normalan proces diferencijacije.

h) Težnja veliko-srpske buržoazije da „nacionalizira“ Kosovo ${ }^{51}$ dovela je s jedne strane do nastojanja da se arnautski živalj po mogućstvu potisne preko granice a turski muslimanski živalj da se natera da svoje imanje proda što jeftinije i da se iseli u Tursku, ${ }^{52}$ a s druge strane do nastojanja da se što više učvrsti aparat ugnjetavanja u toj oblasti. Zato su [se] opštine davale i daju se u ruke otvoreno srpskim agentima, a vlast policije i žandarmerije upravo je neograničena. To činovništvo beskrajno korupcionističko, ne preza kao i u Makedoniji da iz seljaka izvlače zlatne turske lire ([nečitko - prim. D. B.] po starom običaju tih krajeva). Verovatno nigde $u$ Jugoslaviji nije posle rata postojao strašniji teror nad masama nego na Kosovu (paljenje čitavih sela, sl[a]nje velikih vojnih odelenja u sela na duži boravak na račun seljaka, ubijanje istaknutih ljudi). Bez izgleda na ekonomski napredak na industrijalizaciju ovi krajevi su već odavno stali da liferuju iseljenike, pečalbare. Od Skoplja do Beograda, a sigurno i drugde naći ćete arnautske pečalbare, ljude koji redovno rade najteže fizičke poslove a koji žive pod najgorim uslovima. Proletarizacija je normalan proces $u$ seljaštvu te zemlje, naročito u arnautskom i muslimanskom.

j) Razume se da veliko-srpski imperijalizam nastoji da i kulturno utiče na Arnaute i Muslimane. Osim muslimanskih religioznih škola i nekih crkvenih škola za katoličke Arnaute (oko Prizrena) ovde postoje još samo srpske škole. Na neke sopstvene srednje škole to stanovništvo Kosova ne sme ni da pomisli. Procenat Arnauta u srednjim školama iščezavajući je malen, a i to su sve deca begova i trgovaca.

${ }^{50}$ Uredba o naseljavanju „južnih krajeva“ dobila je 1931. snagu zakona, dok je izmenama i dopunama iz juna 1933. trebalo okončati haotično stanje na polju agrarne politike. Više: V. Jovanović, „Tokovi i ishod međuratne kolonizacije Makedonije, Kosova i Metohije", 25-44.

${ }^{51}$ Najviše kolonija bilo je u Gračaničkom, Labskom, Vučitrnskom, Gnjilanskom i Nerodimskom srezu. Pojedini autori navode da je kolonizacija Stare Srbije imala „nacionalni karakter“, dok je u Makedoniji reč pre svega o ekonomskom momentu. Više: В. Јовановић, Јуіословенска яржава и Јужна Србија, 217-218.

52 Procene o broju iseljenih Turaka u periodu od 1918. do 1939. iznose oko 19.000.

Više: В. Јовановић, Јуі̄ословенска gржава и Јужна Србија 1918-1929, 205-206. 
Zaključak. Kao što smo videli, pod srpskom vlašću najveći deo stanovništva Kosova došao je u pravo kolonijalno ropstvo.

a) Otpor protiv nac[ionalnog] ugnjetavanja. Dok su pravi Turci suviše neznatan sloj da bi mogli u većoj meri reagirati na metode srpskog ugnjetavanja, sandžački slovenski muslimani su prvih godina posle rata reagirali obično u formi hajdučkih družina (Jusuf Mekonjić, Husein Boškovićc $^{53}$ i drugi).

b) Najznačajniji je bez sumnje, otpor Arnauta. Zahvaćeni velikim nac[ionalnim] pokretom ostalih Arnauta koji je 1920. g[odine] oterao italijanske okupatorske trupe iz južne Albanije (Valona), ${ }^{54}$ kosovski Arnauti su i sami 1921. g[odine] digli ustanak. I ako je ovaj ustanak u krvi ugušen od srpske vojske, nac[ionalni] otpor time nije pre[... $]^{55}$

c) Pošto su srpske vlasti mnogim Arnautima naprosto otele izvor prihoda, zemlju i stoku, među Arnautima se momenat nac[ionalnog] otpora tesno isprepliće sa potrebom arnautskih seljaka da sebi osiguraju prihode makar i pljačkom. Zato je u pokretu kačaka ${ }^{56}$ teško odvojiti razbojnički momenat od nac[ionalno]-političkog. Ali je nesumnjivo da se kačaci pod Srbima mogu uporediti sa srpskim hajducima Karađorđevog vremena.

d) Još uvek znatno povezani starim plemenskim vezama, a sada još i pod uticajem propagande za Veliku Albaniju, ${ }^{57}$ kosovski Arnauti su u priličnoj meri podupirali rad takozvanog Kosovskog komiteta ${ }^{58}$ (KK) (Hasan-

${ }^{53}$ O delovanju Jusufa Mekonjića i Huseina Boškovića u Sandžaku videti: Ejup Mušović, „Hajdučije i komite u Sandžaku“, Simpozijum: Seoski dani Sretena Vukosavljevića, VI, urednik Petar Vlahović (Prijepolje, Zajednica osnovnog obrazovanja, 1978), 85-93.

${ }^{54}$ Italija je do 2. septembra 1920. povukla svoje jedinice iz Albanije. Više: Петер Бартл, Албани, Оg среgюеї века gо gанас (Београд: Clio, 2001), 182-185.

${ }^{55} \mathrm{Na}$ ovom mestu nedostaje ostatak rečenice.

${ }^{56}$ U Osmanskom carstvu termin „kačak“ (tur. kaçak) označavao je razbojnike, bandite i begunce od zakona. Na jugoslovenskom prostoru kačacima su nazivani „arnautski odmetnici“.

${ }^{57}$ Ideja o uspostavljanju Velike Albanije razvijena u okviru tzv. albanskog nacionalnog preporoda (alb. Rilindja kombëtare) tokom druge polovine 19. veka, a podrazumevala je ujedinjenje „albanskih zemalja“ - Skadarski, Kosovski, Bitoljski i Janjinski vilajet - u jedinstvenu autonomnu celinu unutar Osmanskog carstva, odnosno nezavisnu državu. Najuporniji zagovornici ove ideje bili su albanski glavari okupljeni oko Prizrenske lige (alb. Lidhja e Prizrenit). Više: П. Бартл, н. g., 92-97; Ђорђе Борозан, Велика Албанија: йоријекло ugeje - йракса (Београд: Војноисторијски институт војске Југославије, 1995); Милош Јагодић, Срйско-албански ояноси у Косовском вилајешиу (1878-1912) (Београд: Завод за уџбенике, 2009), 17-93.

${ }^{58}$ Kosovski komitet, odnosno Komitet za nacionalnu odbranu Kosova (alb. Komiteti i Mbrojtjes Kombëtare e Kosovës) osnovan je 7. novembra 1918. u cilju pripajanja Albaniji svih oblasti naseljenih albanskim stanovništvom. Osnivači i vođi Komiteta bili su Hasan Priština, Hodž Kadriu, Ćerim Begoli i Husni Cur, sinovac Bajrama Cura. Sedište organizacije najpre se nalazilo u Skadru, potom u Italiji (1924-1939), a uoči Drugog svetskog rata u Tirani. Više: Goran Antonić, „Kosovski komitet i Kraljevina SHS u svetlu jugoslovenskih izvora 
beg Prištinac, ${ }^{59}$ Bajram [Cur $]^{60}$ i dr) čiji je zadatak bio da radi na prisajedinjenju Kosova Albaniji. Rad KK može se uporediti sa radom VMRO, ali su njegove forme aktivnosti bile nešto drukčije, a opseg rada mnogo skučeniji. Od 1921. do 1925. postojala je između KK i VMRO i uža saradnja. Treba naglasiti da se KK naslanjao na Italiju.

e) Poslednjih godina ne oseća se doduše nikakva veća aktivnost među Arnautima, ali još postoji živi kontakt kosovskih Arnauta sa Albanijom. Nesumnjiva je tendencija da na mesto ranije anarhične kačačke forme borbe stupe nove, moderne forme borbe, moderna nac[ionalna] i klasna borba. Tu promenu uslovljava već sam fakat da su pod Srbijom kosovski Arnauti došli pod vlast prvi put jedne koliko-toliko moderne buržoaske države, u splet kapitalističkih ekonom[skih] odnosa. Kao kod Makedonaca i Crnogoraca, nac[ionalna] borba Arnauta ima u velikoj meri položaje borbe jednog gentilno feudalnog društva protiv ogromnog tereta moderne kap[italističke] države i protiv tereta koje im nameće kapitalizam.

f) Brojna arnautska emigracija koja je nastanjena $u$ Albaniji svim silama podržava plan o formiranju Velike Albanije koja bi imala da obuhvati i arnautske kolonije u Srbiji i Makedoniji. To je u stvari stav italoimperijalizma.

3) Zaključak: ${ }^{61}$

a) Kosovo predstavlja komplikovani mozaik raznih nac[ionalnih] manjina i etnič[kih] grupa.

b) Srpski imperijalizam bacio je ovu oblast u položaj kolonije ne rešivši ni jedan od osnovnih problema te oblasti.

c) Nac[ionalno] pitanje Kosova u osnovi je pitanje tamošnjih Arnauta, Turaka, slov[enskih] Muslimana i manjih grupa (Mađupi, Cigani, Kucovlasi).

d) Koncepcija Velike Albanije ne znači rešavanje tog pitanja, nego samo postavljanje albanskog odnosno italijanskog imperijalizma namesto srpskog. Borba protiv takvog „rešenja“ uslovljena je borbama za izolaciju feudalnog sloja, odvajanjem arnautskih i turskih radnih masa ispod uticaja begova [nečitko - prim. D. B.] bili oni orjentisani velikoalbanski ili srpski

1918-1920“, Istorija 20. veka, 1, (2006), 27-45; Богумил Храбак, „Косовски комитет 1918-

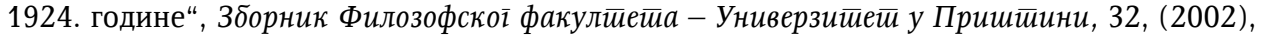
137-163; Владан Јовановић, „Губици југословенске жандармерије у сукобима са качацима и комитама 1918-1934", Токови исйорије, 1-2, (2007), 9-19.

${ }^{59}$ Hasan Priština (Vučitrn, 1873 - Solun, 1933). Jedan od predvodnika Albanaca u Staroj Srbiji, narodni poslanik u albanskom parlamentu (1919) i predsednik vlade (1921).

${ }^{60}$ Bajram Curi (Velika Kruša, 1862 - Dragobi, 1925). Jedan od predvodnika Albana-ca na prostoru Stare Srbije.

${ }^{61}$ Autor je verovatno greškom uneo dva zaključka. 
$\left(\right.$ Cena-beg ${ }^{62}$ ). U tom cilju treba da se organizaciono oformi kosovski nac[ionalno] rev[olucionarni] pokret $u$ duhu levog krila KK Fan Noli-a. ${ }^{63}$

[e)] Rešenje nac[ionalnog] pokreta i ovde se može postići formiranjem slobodne radničko-seljačke republike Kosova putem revolucionarnog obaranja velikosrpskog faš[ističko]-imperijalističkog režima. To rešenje za Arnaute, Turke i slov[enske] Muslimane znači da dođu u punoj meri do slobodnog vlasništva zemlje, da se oslobode nac[ionalnog] ugnjetavanja i da se ostvare uslovi za potpuno slobodan nac[ionalno]-politički i kulturni razvitak. Izgleda da je i srpsko seljaštvo i radništvo tih krajeva već sazrelo da primi tu parolu.

f) Pošto se rešenje može postići samo pod uslovom da proletarijat $u$ toj borbi ostvari svoju ulogu hegemona, osigurati se to rešenje može samo prerastanjem prve etape revolucije $\mathrm{u}$ drugu, u prolet[ersku] revoluciju.

\section{IZVORI I LITERATURA}

Arhiv Jugoslavije. Fond 507, Centralni komitet Saveza komunista Jugoslavije.

Arhiv Jugoslavije. Fond 790/1, Komunistička internacionala.

Izvori za istoriju SKJ, tom I, knj. 10 (Peta zemaljska konferencija KPJ). Priredili Pero Damjanović i drugi. Beograd: Izdavački centar Komunist, 1980.

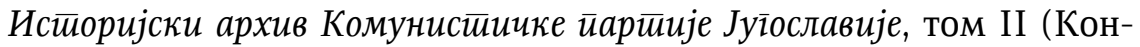
греси и земаљске конференције КПЈ 1919-1937). Београд: Историјско одељење Централног комитета Комунистичке партије Југославије, 1949.

Komunistička internacionala. Stenogrami i dokumenti kongresa, tom XI i XII. Priredili Pero Damjanović i Radosav Đerić. Gornji Milanovac: Institut za međunarodni radnički pokret, 1983.

Antonić, Goran. „Kosovski komitet i Kraljevina SHS u svetlu jugoslovenskih izvora 1918-1920“. Istorija 20. veka, 1, (2006), 27-45.

Апостолски, Михаило и други. Истиорија макеgонскої нароga, IIII. Београд: Завод за издавање уџбеника СРС, 1970.

${ }^{62}$ Cena Riza beg Krueziu (Đakovica, 1895 - Prag, 1927) tokom dvadesetih godina intenzivno je sarađivao sa jugoslovenskim vlastima. Otuda su ga albanski prvaci iz kruga Kosovskog komiteta, potom komunisti i ostali protivnici jugoslovenskog režima optuživali za vođenje srbofilske politike.

${ }^{63}$ Fan (Teofan) Stilijan Noli (Ibrik Tepe, 1882 - Fort Loderdejl, 1965). Političar, pisac i pravoslavni episkop. 
Banac, Ivo. Nacionalno pitanje u Jugoslaviji. Porijeklo, povijest, politika. Zagreb: Globus, 1988. 2001.

Бартл, Петер. Албании. Og среgњеї века gо gанас. Београд: Clio,

Батаковић, Душан Т. Косово и Мет̄охија у срйско-арбанашким о оносима, друго допуњено издање. Београд: Чигоја штампа, 2006.

Борозан, Ђорђе. Велика Албанија: йоријекло - иgеје - иракса. Београд: Војноисторијски институт војске Југославије, 1995.

Вујовић, Димитрије Димо. Црноіорски феgералистии 1919-1929. Титоград: Црногорска академија наука и умјетности, 1981. ИСИ, 1985.

Цветковић, Славољуб. Иgејне борбе у КПЈ 1919-1928. Београд:

Gligorijević, Branislav. Parlament i političke stranke u Jugoslaviji (1919-1929). Beograd: ISI, 1979.

Димић Љубодраг, и Ђорђе Борозан. „Извештаји Министарства унутрашњих дела о злочину и терору на Косову, Метохији и Западној Македонији у првим месецима 1920“. Гоgишњак за gрушишвену исйорију V, 1-3, (1998), 113-123.

Djilas, Milovan. Memoir of a Revolutionary. New York: Harcourt Brace Jovanovich Inc, 1973.

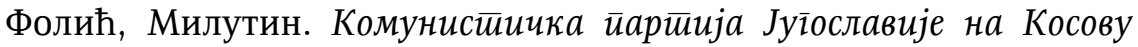
1919-1941. Приштина: Јединство, 1987.

Храбак, Богумил. „Косовски комитет 1918-1924. године“.

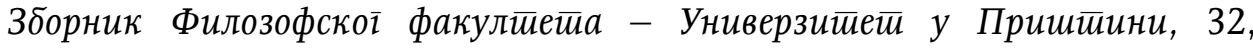
(2002), 137-163.

Храбак, Богумил. Џемијет: орі̄анизаиија муслимана Макеgоније, Косова, Мейохије и Саниака 1919-1928. Београд: ВМД, 2003.

Јагодић, Милош. Срйско-албански оgноси у Косовском вилајейу (1878-1912). Београд: Завод за уџбенике, 2009.

Janjetović, Zoran. Deca careva, pastorčad kraljeva. Nacionalne manjine u Jugoslaviji 1918-1941. Beograd: INIS, 2005.

Јовановић, Владан. Варgарска бановина 1929-1941. Београд: ИНИС, 2011.

Јовановић, Владан. „Губици југословенске жандармерије у сукобима са качацима и комитама 1918-1934“. Токови исйорије, 1-2, (2007), 9-19.

Jovanović, Vladan. „In search of homeland? Muslim migration from Yugoslavia to Turkey 1918-1941". Токови истиорије, 1-2, (2008), 56-67.

Јовановић, Владан. Јуіословенска gржава и Јужна Србија 19181929. Београд: ИНИС, 2002. 
Jovanović, Vladan. „Tokovi i ishod međuratne kolonizacije Makedonije, Kosova i Metohije". Tokovi istorije, 3, (2006), 25-44.

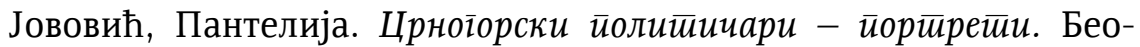
град: Штампарија „Време“, 1924.

Јуі̄ословенска gржава и Албании, I-II. Приредили Љубодраг Димић и Ђорђе Борозан. Београд: Службени лист СРJ, 1998-1999.

Ličina, Đorđe i drugi. Andrija Artuković, Vjekoslav Luburić, Džafer Deva, Vančo Mihailov. Zagreb: Centar za informacije i publicitet, 1985.

Lukač, Dušan. Radnički pokret u Jugoslaviji i nacionalno pitanje 1918-1941. Beograd: ISI, 1972.

Марковић, Мома. Сазревање револуиије (Сећања 1931-1941). Београд: БИГЗ, 1984.

Milićević, Vladeta. Ubistvo kralja u Marselju. Pozadina jednog zločina. Beograd: Filip Višnjić, 2000.

Mušović, Ejup. „Hajdučije i komite u Sandžaku“. U: Simpozijum: Seoski dani Sretena Vukosavljevića VI. Urednik Petar Vlahović, 85-93. Prijepolje: Zajednica osnovnog obrazovanja, 1978.

Пешић, Десанка. Јуіословенски комунистии и наиионално ииитиане (1919-1935). Београд: Рад, 1983.

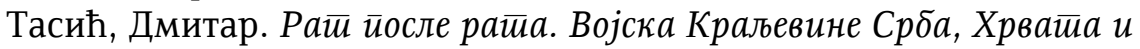
Словенаиа на Косову и Метиохији и у Макеgонији 1918-1920. Београд: Утопија, 2008. 